\title{
Pelaksanaan Penilaian Pembelajaran di Taman Kanak- Kanak (Studi Deskriptif pada Taman Kanak-kanak di Jakarta) ${ }^{1}$
}

\author{
Rohita $^{1}$, Nurfadilah ${ }^{2}$ \\ ${ }^{1,2}$ Program Studi PG PAUD, Fakultas Psikologi dan Pendidikan, Universitas Al Azhar Indonesia, Jl. \\ Sisingamangaraja, Kebayoran, Jakarta Selatan, 12110
}

Penulis untuk Korespondensi/E-mail: rohita@uai.ac.id

\begin{abstract}
Abstrak - Penelitian ini merupakan penelitian kualitatif deskriptif. Adapun tujuan penelitian ini adalah untuk menggambarkan pelaksanaan penilaian pembelajaran di TK. Teknik pengumpulan data menggunakan wawancara, observasi serta dokumentasi. Subjek penelitian adalah lembaga pendidikan anak Taman Kanak-kanak sebanyak 3 lembaga yang dipilih dengan menggunakan teknik purposive sampling. Hasil penelitian diketahui bahwa pelaksanaan penilaian pembelajaran yang dilakukan di tiga TK di wilayah Kapuk, Cengkareng, Jakarta Barat tidak hanya penilaian harian tetapi juga melakukan penilaian semester yang dilaksanakan pada akhir semester pembelajaran, dalam waktu 2 minggu dengan durasi kegiatan $1-1 \frac{1}{2}$ jam untuk setiap rombongan belajar. Setiap kelompok diberi tugas berupa beberapa lembar kerja yang berisi materi sesuai aspek perkembangan anak yang merupakan kumpulan dari materi-materi pada setiap tema yang telah dibahas sebelumnya. Dari hasil penelitian tersebut dapat disimpulkan bahwa 1) penilaian semester yang dilakukan di ketiga TK belum menunjukkan kesesuaian dengan prinsip-prinsip penilaian pembelajaran di TK, yaitu prinsip alami dan bermakna, otentik, holistik, individual serta multisumber dan multikonteks; 2). Guru belum memahami betul subyek penilaian yaitu anak TK usia 4-6 tahun, sehingga memberikan materi soal yang sama antara anak kelompok A dengan anak kelompok B; 3). Pemahaman mengenai sasaran penilaian masih kurang, dimana aspek yang dinilai lebih banyak pada aspek kognitif dan bahasa, serta penggunaan metode pengumpulan data berupa alat penilaian yang lebih dominan menggunakan alat penilaian tes berupa lembar kerja anak; dan 4). Pelaksanaan penilaian pembelajaran khususnya penilaian semester tidak berdampak langsung pada penentuan pembelajaran selanjutnya. Kegiatan untuk pembelajaran berikutnya diberikan dengan melakukan diskusi antar guru mengenai kegiatan apa yang akan diberikan selanjutnya.
\end{abstract}

\section{Kata Kunci - Penilaian Pembelajaran, Anak TK}

Abstract - This study is a qualitative descriptive research. The purpose of this study was to desribe the implementation of the learning assessment in kindergarten. The data collection methods are interview, observation and review documentation. The subjects were kindergarten teachers from 3 different institution in Kapuk, Cengkareng, West Jakarta area. Purposive sampling was chosen as a tool for sample selection. The research revealed that the implementation of learning assesment in Kapuk, Cengkareng area, not only do per day but also per semester, which conducted at the end of semester, within 2 weeks, with duration of action 1$1 \frac{1}{2}$ hour for each learning group. Each group was given a task in a form of worksheets which comprised developmentally appropriate lessons according the themes that has been given before. The conclusion is the assesment which has been conducted in 3 kindergarten has not indicated the congruity with learning principles in kindergarten, namely as principles of natural

\footnotetext{
${ }^{1}$ Paper ini telah diseminarkan di seminar internasional "International Conference On Education And Training" Universitas Negeri Malang pada tanggal 04-06 November 2016
} 
and meaningful, authentic, holistic individualized, resourceful and and multi context; 2) teachers has lack in understanding assesment of the children in age 4-6 years therefore the teacher has given the same matter in grup $A$ and $B ; 3$ )Teachers also has lack of understanding about the purpose of the assesment and therefore they more focus on cognitive and language mastery and using test in a form of worksheets than other form; 4) Learning assesment, especially semesterly, has not direct impact on determining the following lessons. The following lessons will be given as the result of teacher's discussions about the learning activity.

Keywords - Learning Assesment, Kindergarten Children

\section{PENDAHULUAN}

$\mathrm{P}$ endidikan anak usia dini merupakan pendidikan yang ditujukan untuk anak dengan rentang usia 0-6 tahun (UndangUndang Republik Indonesia, No. 20 tahun 2003 tentang Sistem Pendidikan Nasional pasal 1 ayat 14). Di dalam pelaksanaannya rentang usia tersebut terbagi menjadi beberapa kelompok, yang salah satunya adalah rentang usia 4-6 tahun atau yang lebih dikenal dengan usia Taman Kanak-kanak (TK)

Stimulasi yang diberikan di sekolah merupakan tanggung jawab guru. Berbagai stimulasi perlu diberikan agar potensi yang dimiliki anak dapat berkembang secara optimal. Stimulasi yang diberikan harus pula meliputi semua aspek perkembangan anak, yang meliputi aspek perkembangan bahasa, kognitif, moral agama, sosial emosional, seni dan fisik motorik. Pemberian stimulasi harus sesuai dengan karakteristik, kemampuan anak serta prinsip belajar anak. Instruksi diatur berdasarkan kebutuhan, minat, dan gaya belajar anak. Penekanan diletakkan pada proses belajar, dibandingkan pada apa yang dipelajari (Feeney dkk, 2010; Henrick\&Weiss-man, 2010).

Taman kanak-kanak yang berpusat pada anak mempertahankan tiga prinsip: setiap anak mengikuti sebuah pola perkembangan yang unik, anak-anak kecil belajar melalui pengalaman langsung dengan berbagai orang dan materi, dan bermain merupakan hal yang sangat penting bagi perkembangan anak secara total. Bereksperimen, bereksplorasi, menemukan, mencoba, melakukan restrukturisasi, berbicara, dan mendengarkan, merupakan aktivitas-aktivitas yang seharusnya ada dalam program taman kanak-kanak, karena sangat sesuai dengan status perkembangan anak usia 4 hingga 5 tahun.
Bermain menjadi salah satu ciri dari anak usia dini. Pembelajaran yang dikemas dalam upaya pemberian stimulasi harus dapat dievaluasi. Berbagai kegiatan yang dilakukan anak harus juga dapat dinilai guna mengetahui tingkat ketercapaian pembelajaran yang telah dilakukan. Penilaian tersebut hendaknya dilakukan pada saat anak melakukan kegiatan yang telah disusun oleh guru. Penilaian dilakukan pada semua aspek perkembangan anak. Dengan demikian guru dapat mengetahui dengan jelas bagaimana kemampuan anak. Hasil penilaian hendaknya dapat digunakan tidak hanya untuk guru tetapi juga untuk orangtua bahkan untuk anak itu sendiri.

Kenyataan di lapangan, masih ada sekolahsekolah atau lembaga pendidikan anak usia dini dalam hal ini TK yang melakukan penilaian dengan membuat jadwal khusus untuk "ujian". Setiap anak diberi beberapa lembar kertas yang berisi soal-soal sederhana untuk diselesaikan anak. Materi soal yang terdapat di dalam lembar kertas "ujian" juga hanya berfungsi untuk menilai kemampuan kognitif anak. sementara untuk aspek lain terutama aspek moral agama, sosial emosional dan motorik (kasar) tidak dapat diukur.

Sementara itu, Leonard (dalam Brewer, 2007: 207) menuliskan bahwa:

“..observation helps teachers get to know children as individuals with unique personalities, provides a basis for making educational decisions, and generates the data needed to help parents see and understand their children's progress."

Dengan kata lain bahwa, dengan melakukan observasi sebagai alat penilaian, guru dapat melihat banyak hal dalam diri anak terkait dengan perkembangan dan kemampuannya. 
Melihat fenomena tersebut, dirasa perlu untuk melakukan pengamatan lebih jauh dalam bentuk penelitian mengenai pelaksanaan penilaian di Taman Kanak-kanak.

Adapun rumusan masalah dalam penelitian ini adalah:

1. Bagaimanakah pelaksanaan penilaian pembelajaran di Taman Kanak-kanak?

2. Apakah dampak pelaksanaan penilaian pembelajaran pada penentuan kegiatan pembelajaran selanjutnya?

Berdasarkan latar belakang masalah tersebut maka, tujuan penelitian ini adalah:

1. Untuk menggambarkan pelaksanaan penilaian pembelajaran di Taman Kanakkanak

2. Untuk mengetahui dampak penilaian pada penentuan kegiatan pembelajaran selanjutnya.

\section{Penilaian Pembelajaran}

Anak usia 4-6 tahun menurut National Association for the Education of Young Children (NAEYC) termasuk dalam kelompok preschool (3-5tahun). Sementara di UndangUndang Republik Indonesia anak usia 4-6 tahun masuk dalam kelompok Pendidikan jalur formal yaitu Taman Kanak-Kanak (TK). Pada kelompok usia ini karakteristik mereka berbeda dengan karakteristik kelompok usia lainnya. Berikut adalah karakteristik anak usia prasekolah menurut pada ahli (Anita Yus, 2011: 18)

Berdasarkan Peraturan Menteri Pendidikan dan Kebudayaan No 147 Tahun 2014, diketahui bahwa anak usia 4-6 tahun memiliki tingkat pencapaian perkembangan yang harus dicapai. Tingkat pencapaian perkembangan tersebut meliputi seluruh aspek perkembangan anak, yaitu perkembangan moral agama, perkembangan sosial emosional, perkembangan bahasa, perkembangan fisik motorik, perkembangan kognitif, dan perkembangan seni. Keenam aspek perkembangan tersebut harus dapat dinilai untuk mengetahui tingkat pencapaian yang dimiliki anak berdasarkan indikator-indikator yang ada.

Menurut Ralph Tyler (dalam Anita Yus, 2011: 39), penilaian merupakan sebuah proses pengumpulan data untuk menentukan sejauh mana, dalam hal apa dan bagian mana dari tujuan pendidikan sudah tercapai. Sementara Brewer (dalam Anita Yus, 2011: 39) menuliskan bahwa penilaian adalah penggunaan sistem evaluasi yang bersifat komprehensif (menyeluruh) untuk menentukan kualitas dari suatu program atau kemajuan dari seorang anak.

Berbeda dengan beberapa pendapat di atas, Suyanto (2005: 49) menuliskan bahwa di TK digunakan istilah asesmen. Lebih lanjut beliau menuliskan bahwa asesmen berbeda dengan evaluasi. Asesmen merupakan proses pengamatan, pencatatan, dan pendokumentasian kemampuan dan karya anak sebagai dasar pengambilan keputusan pendidikan yang bermanfaat bagi anak. Berdasarkan hal tersebut dapat diketahui bahwa untuk mengetahui berbagai kemampuan anak dan agar dapat diambil sebuah keputusan yang bermanfaat bagi anak maka perlu kiranya dilakukan sebuah asesmen, yang meliputi proses pengamatan, pencatata dan pendokumentasian.

Di dalam pelaksanaan penilaian, guru harus memahami dua hal yaitu subyek penilaian dan sasaran penilaian (Anita Yus, 2011: 47-48 ). Terkait dengan subyek penilaian, guru harus mengenal betul siapa yang akan dinilai. Guru anak usia TK berarti akan menilai anak usia TK yaitu usia 4-6 tahun. Dengan demikian guru harus benar-benar mengetahui siapa anak usia TK tersebut, bagaimana karakteristiknya, apa yang akan dinilai dari anak usia TK, bagaimana menilainya, alat apa yang akan digunakan, kapan melakukan penilaian tersebut, untuk apa penilaian dilakukan, dan hal-hal penting lainnya.

Selain mengenal subyek penilaian, guru juga harus mengetahui sasaran penilaian. Suharsimi dalam Anita Yus (2011: 48) mengemukakan bahwa sasaran atau objek penilaian adalah segala sesuatu yang menjadi pusat pengamatan karena penilai menginginkan informasi tentang sesuatu ini. Lebih lanjut, Suharsimi (dalam Anita Yus, 2011: 48 ) menuliskan bahwa sasaran penilaian meliputi unsur input, transformasi dan output. Unsur input meliputi potensi yang ingin dikembangkan dari diri anak yang terdiri dari 6 aspek perkembangan yaitu, fisik, kognitif, bahasa, sosial emosional, seni dan moral agama. Unsur transformasi meliputi materi, metode, media, sistem administrasi dan 
guru. Sementara unsur output meliputi seberapa jauh anak mencapai tujuan yang telah ditetapkan atau seberapa jauh anak memiliki dasar-dasar untuk pertumbuhan dan perkembangan diri selanjutnya.

Penilaian atau asesmen seharusnya dilakukan terus menerus. Hal ini sesuai dengan apa yang dituliskan Suyanto (2005: 49-50) yaitu bahwa asesmen (penilaian) dilakukan terus menerus sejalan dengan kegiatan pembelajaran. Asesmen dilakukan secara alami, yaitu pada saat anak bermain, menggambar atau membuat karya. Hal ini sesuai pula dengan apa yang dituliskan Anita Yus (2011: 64) yaitu bahwa terkait dengan tempat dan waktu penilaian, penilaian yang akan dilakukan harus disesuaikan dengan kebutuhan penilaian dan anak yang akan dinilai serta rancangan kegiatan pelaksanaan program yang digunakan. Untuk anak usia dini, tempat dan waktu penilaian dilakukan sesuai dengan waktu kegiatan pelaksanaan program itu sendiri.

Untuk dapat melaksanakan asesmen atau penilaian dengan baik dan benar, hendaknya guru memahami betul prinsip-prinsip asesmen untuk anak TK, yaitu 1. Holistik, 2. Otentik, 3. Kontinyu, 4. Alami dan bermakna, 5. Individual, dan 6. Multisumber dan multikonteks. (Suyanto, 2005: 50-51). Melakukan penilaian tentu perlu menggunakan alat penilaian. Di dalam lembaga pendidikan anak usia dini termasuk TK, alat penilaian yang digunakan umumnya berupa alat penilaian non tes, yang terdiri dari pemberian tugas, observasi, percakapan, catatan anekdot, serta portofolio. Di dalam bukunya, Wolfgang \& Wolfgang (1992: 213) menuliskan bahwa "the primary assessment tool of the play-activity (child-centered) curriculum is the direct observation of children." Berdasarkan apa yang dituliskan Wolfgang \& Wolfgang tersebut jelas bahwa untuk anak usia dini yang terfokus pada kegiatan bermain, maka alat penilaian yang digunakan adalah dengan pengamatan langsung.

Lebih lanjut, Deb Curtis and Margie Carter (2008: 214) menuliskan panduan tentang nilainilai atau perspektif yang diharapkan serta pencatatan yang dapat dilakukan dalam tabel berikut.

Tabel 1. Clarity on Values and Theoretical Perspective and Their Outcomes in Practice.

\begin{tabular}{|c|c|c|c|c|}
\hline $\begin{array}{c}\text { Perspectivel } \\
\text { Values }\end{array}$ & $\begin{array}{l}\text { Theoritical } \\
\text { Assumption }\end{array}$ & $\begin{array}{l}\text { Practical } \\
\text { Outcomes }\end{array}$ & Pedagogy & $\begin{array}{l}\text { Record } \\
\text { Keeping }\end{array}$ \\
\hline $\begin{array}{l}\text { Readiness/ } \\
\text { preparation for } \\
\text { the future }\end{array}$ & $\begin{array}{l}\text { Behaviorism } \\
\text { (Skinner } \\
\text { 1965) }\end{array}$ & $\begin{array}{l}\text { Preparation } \\
\text { School }\end{array}$ & $\begin{array}{l}\text { Teacher } \\
\text { directs and } \\
\text { controls } \\
\text { outcomes }\end{array}$ & Checklist \\
\hline $\begin{array}{l}\text { Developmental/p } \\
\text { rotection }\end{array}$ & $\begin{array}{l}\text { Developmenta } \\
\text { l psychology } \\
\text { (Piaget 2OO1) }\end{array}$ & $\begin{array}{l}\text { Notion of } \\
\text { universal child } \\
\text { moving } \\
\text { through } \\
\text { predetermined } \\
\text { set of } \\
\text { developmental } \\
\text { milestones. } \\
\text { Teachers plan } \\
\text { experiences to } \\
\text { meet these }\end{array}$ & $\begin{array}{l}\text { Teacher } \\
\text { guides } \\
\text { children } \\
\text { through } \\
\text { verbal and } \\
\text { physical } \\
\text { support. } \\
\text { Helps with } \\
\text { conflict } \\
\text { resolution. } \\
\text { Teacher } \\
\text { facilitates, } \\
\text { providing } \\
\text { experiences } \\
\text { with time } \\
\text { and space } \\
\text { to extend } \\
\text { and } \\
\text { challenge } \\
\text { children's } \\
\text { interest }\end{array}$ & $\begin{array}{l}\text { Use of child } \\
\text { observation } \\
\text { s linked } \\
\text { directly to } \\
\text { planning } \\
\text { learning } \\
\text { experience }\end{array}$ \\
\hline $\begin{array}{l}\text { Foster group } \\
\text { and individual } \\
\text { identity }\end{array}$ & $\begin{array}{l}\text { Sociocultural } \\
\text { theories } \\
\text { (Vygotsky, } \\
\text { Bronfenbrenn } \\
\text { er, Rogoff }\end{array}$ & $\begin{array}{l}\text { Children } \\
\text { construct own } \\
\text { knowledge } \\
\text { through } \\
\text { interaction } \\
\text { with others }\end{array}$ & $\begin{array}{l}\text { Teacher } \\
\text { scaffolds } \\
\text { learning } \\
\text { and } \\
\text { complexity } \\
\text { through } \\
\text { play }\end{array}$ & $\begin{array}{l}\text { Collections } \\
\text { of samples } \\
\text { of } \\
\text { children's } \\
\text { work in } \\
\text { portfolios } \\
\text { with that } \\
\text { documentati } \\
\text { on explains } \\
\text { learning } \\
\text { goals }\end{array}$ \\
\hline
\end{tabular}


Berdasarkan tabel di atas dapat diketahui bahwa pendidik dapat melakukan penilaian dalam bentuk ceklist, observasi ataupun mengumpulkan hasil karya anak dalam bentuk portofolio yang penggunaannya disesuaikan dengan perspektif atau masing-masing nilai yang ingin dikembangkan.

Hasil penilaian yang diperoleh diberikan kepada orangtua dalam bentuk narasi yang menggambarkan kemampuan yang telah dicapai anak yang meliputi aspek pertumbuhan dan perkembangan. Hasil penilaian yang diperoleh harus dapat menjawab pertanyaan tentang sebaik apa hasil atau prestasi belajar seorang peserta didik. Howard Gardner (dalam Anita Yus, 2011: 39) menegaskan bahwa penilaian merupakan upaya memperoleh informasi mengenai keterampilan dan potensi diri individu dengan dua sasaran, pertama, memberikan umpan balik yang bermanfaat kepada individu yang bersangkutan. Kedua, sebagai data yang berguna bagi masyarakat yang ada di sekitarnya.

Anak usia 4-6 tahun menurut National Association for the Education of Young Children (NAEYC) termasuk dalam kelompok preschool (3-5tahun). Sementara di UndangUndang Republik Indonesia anak usia 4-6 tahun masuk dalam kelompok Pendidikan jalur formal yaitu Taman Kanak-Kanak (TK). Pada kelompok usia ini karakteristik mereka berbeda dengan karakteristik kelompok usia lainnya. Berikut adalah karakteristik anak usia prasekolah menurut pada ahli (Anita Yus, 2011: 18)

Berdasarkan Peraturan Menteri Pendidikan dan Kebudayaan No 147 Tahun 2014, diketahui bahwa anak usia 4-6 tahun memiliki tingkat pencapaian perkembangan yang harus dicapai. Tingkat pencapaian perkembangan tersebut meliputi seluruh aspek perkembangan anak. Berikut adalah tabel tingkat pencapaian perkembangan anak usia 4-6 tahun.

\section{Metode Penelitian}

Penelitian ini dilakukan dengan menggunakan metode penelitian kualitatif. Penelitian kualitatif merupakan penelitian yang ingin mengungkap situasi sosial tertentu dengan mendeskripsikan kenyataan secara benar, dibentuk oleh kata-kata berdasarkan teknik pengumpulan dan analisis data yang relevan yang diperoleh dari situasi yang alami (Ghony \& Almanshur, 2012: 26). Sampel penelitian adalah TK-TK di daerah Jakarta Barat. Pengumpulan data dilakukan dengan menggunakan observasi, wawancara, dokumentasi dan triangulasi. (Ghony \& Almanshur, 2012: 26).

Analisis data dilakukan dalam dua tahapan, yaitu selama proses pengumpulan data dan pada akhir pengumpulan data, yang dilakukan dengan jalan bekerja dengan data, mengorganisasikan data, memilah-milahnya menjadi satuan unit yang dapat dikelola, mensintesiskannya, mencari dan menemukan pola, menemukan apa-apa yang penting dan apa-apa yang dipelajari dan memutuskan apaapa yang dapat diceritakan kepada orang lain. Ghony \& Almanshur, 2012: 247)

\section{HASIL PENELITIAN DAN PEMBAHASAN}

\section{TK Baitul Uyun}

Adanya tuntutan masyarakat agar anakanaknya bisa membaca, menulis dan berhitung ketika keluar dari TK dan agar mereka siap memasuki pendidikan di SD, mengakibatkan guru lebih menitikberatkan pendidikan yang diberikan kepada anak pada kegiatan calistung tersebut. Setiap hari, anak distimulasi dengan kegiatan-kegiatan yang mendukung mereka untuk mampu membaca, menulis dan berhitung. Aspek perkembangan lain tetap diperhatikan, namun dengan porsi yang tidak seimbang.

Penilaian semester dilakukan pada Bulan Mei, dimulai pada Senin hingga Jum'at, 09-13 Mei 2016. Penilaian semester hari pertama, Senin 09 Mei 2016 dimulai pukul 07.00-08.30 untuk rombel I. Sementara untuk rombel II dimulai pukul 08.45. Anak-anak duduk di kelas masing-masing sesuai dengan tempat yang disediakan. Anak kelompok B1 belajar dengan bu Uryati sejumlah 8 orang, kelompok B2 dengan bu Diana sejumlah 7 orang, kelompok B3 dengan bu Eneng sejumlah 7 orang. Sementara bu Fitri dengan anak PAUD. Adapun jadwal penilaian semester disajikan pada tabel berikut: 
Tabel 2. Jadwal Semester II TK Baitul Uyun

\begin{tabular}{|c|c|c|}
\hline $\begin{array}{l}\text { Senin, } 9 \text { Mei } \\
2016\end{array}$ & $\begin{array}{l}\text { Selasa, } \\
\text { Mei } 2016\end{array}$ & $\begin{array}{l}\text { Rabu, } 11 \text { Mei } \\
2016\end{array}$ \\
\hline Perkembanga & Perkembanga & Perkembanga \\
\hline n Bahasa & n Kognitif & $\begin{array}{l}\text { n Bahasa } \\
\text { (Reseptif) }\end{array}$ \\
\hline Kamis, 12 & Jumat, 13 & Senin, $16 \mathrm{Mei}$ \\
\hline $\begin{array}{l}\text { Me1 2010 } \\
\text { Bahasa }\end{array}$ & $\begin{array}{l}\text { Me1 } 2010 \\
\text { Perkembanga }\end{array}$ & Perkembanga \\
\hline $\begin{array}{l}\text { Mandarin, } \\
\text { Inggris, Arab }\end{array}$ & $\begin{array}{l}\text { n Moral dan } \\
\text { Agama }\end{array}$ & $\begin{array}{l}\text { n Seni, 3M } \\
\text { (mewarnai, } \\
\text { menggunting, } \\
\text { menempel) }\end{array}$ \\
\hline
\end{tabular}

Kegiatan penilaian semester dimulai dengan memberikan kertas tugas untuk diberi nama masing-masing anak. setelah anak selesai menuliskan nama mereka, guru menjelaskan cara menyelesaikan lembar tugas yang diberikan dengan mencontohkannya di papan tulis. Tugas yang diberikan untuk anak kelompok A dan kelompok B sama, namun untuk kelompok PAUD tidak sama.

Tugas pertama untuk kelompok B adalah mencontoh huruf abjad pada tempat yang disediakan. Tugas kedua untuk kelompok B adalah mengisi titik-titik dengan cara membaca bersama-sama kemudian menuliskan jawabannya sendiri-sendiri. Tugas guru dalam kegiatan penilaian semester selain menjelaskan tugas yang harus diselesaikan, juga membimbing anak-anak yang tidak dapat mengerjakan soal yang diberikan. Bagi anak yang tidak bisa menulis kata dengan lengkap, guru membantu memperbaiki kata-kata yang hurufnya kurang. Guru juga memotivasi anak dan memberi reward dengan kata-kata "kamu pintar" bagi yang berhasil. Untuk kelompok B diberikan tiga lembar tugas untuk aspek perkembangan bahasa.

Sementara tugas yang harus diselesaikan anak kelompok PAUD adalah sejumlah 2 lembar. Tugas pertama adalah menulis sesuai contoh di papan tulis pada tempat yang disediakan. Tugas kedua adalah menarik garis gambar binatang sesuai huruf awalnya. Sebelum mengerjakan tugas, guru menjelaskan lebih dulu cara mengerjakan tugas tersebut. Guru mencontohkannya dengan membuat gambar buah nanas di papan tulis. Kemudian guru menanyakan apa huruf awal kata nanas anakanak menjawab "s". Bagi anak PAUD yang tidak dapat menyelesaikan tugas menulis huruf guru membantunya dengan cara menuliskan huruf tersebut.

Secara umum kegiatan semester yang dilaksanakan pada hari Senin berjalan lancar, namun hal tersebut membuat emosi guru terpancing. Di dalam prosesnya guru juga mengingatkan agar anak tidak mencontek dan mengerjakan tugasnya sendiri-sendiri. Jika ada jawaban anak yang salah, guru membantu memperbaikinya. Guru juga mengingatkan agar anak menulis kata dengan mengeja hurufnya terlebih dahulu. Untuk anak kelompok B, soalsoal yang ada di dalam tugas yang harus diselesaikan meliputi beberapa tema yang telah dibahas sebelumnya, termasuk tema transportasi. Namun pada saat anak diminta menyebutkan dan membedakan media cetak dan media elektronik, anak terlihat masih kesulitan, sehingga perlu usaha ekstra guru dalam menjelaskan materi tersebut agar anak mampu menyelesaikan tugas penilaian semester yang diberikan hari itu.

Setelah kegiatan penilaian semester selesai dikerjakan anak, guru menjelaskan kegiatan tes untuk diselesaikan esok hari, baik untuk anak kelompok B maupun untuk anak kelompok PAUD.

\section{TK Mutiara Ilmu}

Terkait dengan diadakannya kegiatan penilaian semester hal itu dikarenakan adanya pertanyaan dari masyarakat mengenai waktu diselenggarakannya "tes". Sebagian besar orang tua peserta didik di TK Mutiara Ilmu "mengetahui" bahwa TK-TK di sekitar lingkungan mereka melaksanakan tes pada setiap semester, sehingga hal tersebut perlu pula dilakukan di TK Mutiara Ilmu tempat anak-anak mereka mendapatkan pendidikan. Hal ini yang mendorong sekolah untuk menyelenggarakan penilaian pada setiap semester.

Pada dasarnya kegiatan penilaian semester itu sendiri adalah pengulangan dari materi yang diberikan sebelumnya sesuai dengan tema yang telah disampaikan. Hanya saja materi tersebut dikumpulkan, dibuat seperti soal, ditulis dalam beberapa lembar kertas dan diberikan pada anak untuk diselesaikan pada satu waktu tertentu. Pelaksanaan penilaian semester di TK Mutiara Ilmu dimulai Senin 16 Mei 2016 hingga Jumat 20 Mei 2016. Kepala sekolah 
tidak membuat jadwal kegiatan untuk penilaian semester, semuanya berjalan begitu saja. Tugas untuk hari Senin adalah berhitung dan bahasa, Selasa adalah berhitung dan bahasa, Rabu adalah Mewarnai dan bahasa Inggris, Kamis adalah bahasa dan berhitung, sementara Jumat adalah bahasa Inggris dan seni (mewarnai).

Observasi sendiri dilakukan pada Rabu, 18 Mei 2016. Kegiatan dimulai pukul 07.30-09.00 untuk rombel I dan pukul 09.00-10.30 untuk rombel II. Namun anak kelompok A dan kelompok B belajar bersama dalam 1 waktu karena keinginan anak untuk belajar pagi. Tugas yang diberikan untuk kelompok $\mathrm{A}$ dan kelompok B berbeda namun dengan jumlah lembar tugas yang sama yaitu 2 lembar. Di hari Rabu ini, tugas yang harus diselesaikan anak adalah mewarnai dan menghubungkan dalam bahasa Inggris. Untuk bahasa Inggris, soal dan tugas yang diberikan sama antara kelompok A dan kelompok B, namun untuk mewarnai kelompok A diberikan gambar yang lebih sederhana yaitu gambar kupu-kupu dibandingkan dengan gambar untuk kelompok B yaitu gambar orang Jawa.

Untuk bahasa Inggris, anak mengerjakannya bersama-sama dalam satu tempat berbentuk persegi sehingga tidak dapat terlihat mana anak yang sudah bisa dan mana anak yang belum bisa. Di dalam penyelesaiannya, guru tetap membantu anak-anak dengan menginstruksikan apa yang harus dilakukan, apa arti dari sebuah kata dalam bahasa Inggris tanpa melihat tugas anak satu per satu dan anak-anak yang menjawabnya. Pada saat anak selesai mengerjakan tugas, guru meminta anak untuk menuliskan nama mereka masing-masing, namun tidak ada tempat yang disediakan untuk menuliskan nama anak sehingga anak-anak sering lupa untuk menuliskan nama mereka. Demikian pula tempat untuk memberikan nilai dari hasil kerja anak, tidak disediakan.

Observasi kedua dilakukan pada Jumat, 20 Mei 2016. Kegiatan yang diberikan adalah aspek bahasa baik untuk anak kelompok A maupun anak kelompok B. Anak menyelesaikan tugas dengan bantuan guru yang menyuruhnya dengan "tunjuk dan baca kalimatnya, cari jawabannya". Anak diminta membaca kalimatnya dengan baik-baik, jika tidak bisa guru yang membacakannya. Ketika anak menjawab dengan benar guru meminta anak mencari tulisan sesuai jawabannya. Dalam menyelesaikan tugasnya anak juga diajarkan untuk tidak menyontek. Jika ada anak yang salah dalam menuliskan kata, maka anak diminta memperbaikinya kembali. Hasil kegiatan semester ini diberikan bersamaan dengan pembagian rapot. Hasil kegiatan semester tidak selalu menjadi dasar untuk kegiatan berikutnya.

\section{TK Cahaya Prima}

TK Cahaya Prima sebagai salah satu TK di wilayah Kapuk, Cengkareng, Jakarta Barat juga mengadakan penilaian semester bagi anak-anak didiknya. Alasan diadakannya semesteran adalah untuk mengetahui pencapaian hasil belajar anak selama 1 semester. Penilaian semester tersebut akan digunakan untuk pengisian rapot, yaitu membantu atau sebagai nilai tambahan kegiatan sehari-hari dan penilaian semester ini tidak keseluruhan masuk ke dalam pengisian raport. Raport sendiri diisi dalam bentuk narasi tentang perkembangan anak selama 1 semester dan tidak menggunakan penilaian angka namun nilai dikembangkan dari kategori * (bintang) yang didapat anak.

Berdasarkan wawancara yang dilakukan pada 6 Mei 2016 diperoleh informasi bahwa penilaian semester di TK Cahaya Prima akan dilakukan selama 1 minggu dimulai Senin, 16 Mei 2016 hingga Jumat, 20 Mei 2016. Namun kenyataannya dikarenakan beberapa hal, sekolah merubah jadwal penilaian semester menjadi Senin, 9 Mei hingga Jumat, 13 Mei 2016. Perubahan tersebut tidak dikomunikasikan kembali dengan peneliti dikarenakan kesibukan kepala sekolah yang mengakibatkan lupa untuk memberitahukan peneliti. Informasi mengenai pelaksanaan penilaian semester di TK Cahaya Prima diperoleh hanya pada hari terakhir kegiatan semester yaitu Jumat, 13 Mei 2016. Hal ini dikarenakan pada hari itu tim peneliti berencana untuk melakukan wawancara dengan kepala sekolah untuk melengkapi beberapa data yang dibutuhkan. Namun dikarenakan jarak yang cukup jauh dari kampus, tim peneliti datang ke TK Cahaya Prima pada saat kegiatan semester sudah selesai. Sehingga tim peneliti tidak dapat melihat langsung proses kegiatan penilaian. Tim peneliti hanya dapat memperoleh beberapa informasi yang 
dilengkapi dengan beberapa foto hasil kerja anak.

TK Cahaya Prima tidak membuat jadwal semesteran secara tertulis. Untuk kegiatan penilaian semester tugas yang diberikan sesuai aspek perkembangan anak. Hari pertama tugas untuk perkembangan bahasa, hari kedua tugas untuk perkembangan kognitif, hari ketiga dan keempat tidak diketahui, sementara hari yaitu Jumat 13 Mei 2016 tugas untuk perkembangan seni.

Berdasarkan hasil wawancara dan hasil observasi yang dilakukan beberapa selama beberapa kali ke TK Baitul Uyun, TK Mutiara Ilmu dan TK Cahaya Prima diketahui bahwa ketiga TK tersebut melaksanakan apa yang dinamakan sebagai penilaian semester. Pada dasarnya ketiga sekolah telah melakukan penilaian yang merupakan sebuah proses pengumpulan data untuk menentukan sejauh mana, dalam hal apa dan bagian mana dari tujuan pendidikan sudah tercapai. (Ralph Tyler dalam Anita Yus, 2011). Kepala sekolah, guru maupun beberapa orangtua menyebut penilaian semester yang dilaksanakan tersebut sebagai "tes". Pelaksanaan penilaian semester itu sendiri berdasarkan adanya permintaan orang tua maupun keinginan sekolah untuk mengetahui perkembangan atau kemampuan anak didiknya selama 1 semester. Namun, meskipun diadakannya kegiatan penilaian semester atau yang orang tua sebut sebagai "tes" adalah karena juga merupakan keinginan orangtua, 8 dari 14 orangtua mengatakan bahwa mereka merasa deg-degan, khawatir dan juga takut. Sementara dari sisi anak sendiri 4 dari 8 orang tua mengakui bahwa anak merasa takut, deg-degan, tegang dan gemetaran, sehingga orangtua membantu dan membimbing anak-anaknya belajar dan berlatih di rumah agar dapat mengikuti pelajaran di sekolah.

Pelaksanaan penilaian semester di ketiga TK tersebut dilaksanakan dalam waktu satu minggu dimulai Senin hingga Jumat dengan waktu seperti waktu untuk sekolah, namun lama waktu belajarnya lebih pendek dibandingkan lamanya kegiatan belajar mengajar pada hari biasa. Hal ini tidak sesuai dengan prinsip penilaian dimana penilaian harus dilakukan terus menerus sejalan dengan kegiatan pembelajaran. Penilaian juga dilakukan secara alami, yaitu pada saat anak bermain, menggambar atau membuat karya (Suyanto, 2005). Penilaian untuk anak usia dini, tempat dan waktu penilaian dilakukan sesuai dengan waktu kegiatan pelaksanaan program itu sendiri (Anita Yus, 2011).

Tugas yang diberikan kepada anak baik kelompok A maupun kelompok B untuk TK Baitul Uyun adalah sama. Sementara untuk TK Mutiara Ilmu satu tugas yaitu bahasa Inggris diberikan sama untuk 2 kelompok A dan B, namun tugas lainnya berbeda. Di TK Cahaya Kapuk tugas yang diberikan berbeda antara kelompok A dan kelompok. Semua tugas yang diberikan kepada anak di ketiga TK sesuai dengan aspek perkembangan anak namun banyaknya tugas yang diberikan kepada anak pada masing-masing TK juga berbeda. Di TK Mutiara Ilmu tugas yang diberikan sejumlah 23 lembar, di TK Mutiara Ilmu sejumlah 2 lembar dan di TK Cahaya Prima sejumlah 1 lembar. Hal tersebut tidak sesuai dengan tugas guru dalam memahami subyek penilaian, dimana guru harus mengenal betul siapa yang akan dinilai (anak TK usia 4-6 tahun), bagaimana karakteristiknya, apa yang akan dinilai dari anak usia TK, bagaimana menilainya, alat apa yang akan digunakan, kapan melakukan penilaian tersebut, serta untuk apa penilaian dilakukan (Anita Yus, 2011)

Materi yang terdapat dalam tugas yang diberikan kepada anak lebih dominan untuk aspek perkembangan bahasa dan kognitif. Hal ini diketahui dari jadwal tertulis di TK Baitul Uyun dan kegiatan di TK Mutiara Ilmu. Di kedua TK tersebut tidak dilakukan penilaian untuk aspek perkembangan sosial emosional anak, sementara di TK Mutiara Ilmu selain sosial emosional, penilaian untuk perkembangan moral dan agama juga tidak terlihat dilakukan. Sementara untuk aspek perkembangan seni diberikan satu kali dari 5 hari pelaksanaan kegiatan penilaian semester.

Apa yang dilakukan dikedua TK belum mencerminkan sasaran penilaian secara utuh, yang meliputi unsur input, transformasi dan output. Unsur input meliputi potensi yang ingin dikembangkan dari diri anak yang terdiri dari 6 aspek perkembangan yaitu, fisik, kognitif, bahasa, sosial emosional, seni dan moral agama. Sementara dalam unsur transformasi yang meliputi materi, metode, media, sistem 
administrasi dan guru, juga belum tampak sepenuhnya. Hal ini terlihat dari materi yang sama yang diberikan untuk kelompok usia anak yang berbeda. Dari sisi metode sebagai cara pengumpulan data serta alat penilaian, yang digunakan, pemberian tugas padahal penilaian dapat dilakukan dengan cara yang lain seperti observasi, percakapan, catatan anekdot serta portofolio. Diantara berbagai metode yang dapat digunakan, observasi adalah cara terbaik dalam melakukan penilaian bagi anak usia TK (Wolfgang \& Wolfgang, 1992)

Sementara unsur output meliputi seberapa jauh anak mencapai tujuan yang telah ditetapkan atau seberapa jauh anak memiliki dasar-dasar untuk pertumbuhan dan perkembangan diri selanjutnya cukup dapat terlihat. Hal ini dapat diketahui dari adanya laporan perkembangan anak yang diberikan kepada orangtua dalam bentuk rapot. Rapot tersebut berisi berbagai indikator yang harus dicapai anak serta kategori kemampuan anak. Di dalam rapot tersebut juga dilengkapi bagian yang diisi guru secara naratif terhadap kemampuan yang dimiliki anak sehingga orangtua dapat mengetahui perkembangan anak-anaknya. Hal ini sesuai dengan Howard Gardner (dalam Anita Yus, 2011) yang menegaskan bahwa penilaian merupakan upaya memperoleh informasi mengenai keterampilan dan potensi diri individu.

Di dalam pelaksanaannya guru tetap membantu anak-anak didik yang belum memahami tugas yang harus dikerjakan maupun anak yang belum dapat menyelesaikan tugas sesuai dengan yang diinstruksikan. Reward berupa pujian juga diberikan guru kepada anak yang sudah dapat menyelesaikan tugas dengan baik dan benar, hal ini terutama dilakukan oleh guru di TK Baitul Uyun. Sementara di TK Mutiara Ilmu anak-anak yang memiliki hasil yang bagus akan memperoleh piala sebagai reward dari sekolah.

Tugas-tugas yang diberikan merupakan pengulangan materi yang sudah didiskusikan pada tema-tema selama 1 semester sebelumnya. Hasil dari kegiatan penilaian semester tidak selalu digunakan untuk dasar kegiatan pembelajaran berikutnya, baik di TK Baitul Uyun maupun di TK Mutiara Ilmu. Hasil dari penilaian semester lebih digunakan untuk mengisi rapot, yang digunakan sebagai nilai tambahan dari nilai kegiatan sehari-hari. Hal ini dapat dikatakan bahwa informasi yang diperoleh dari penilaian semester belum dapat dimanfaatkan untuk merencanakan kegiatan pembelajaran berikutnya.

\section{KESIMPULAN DAN SARAN}

Berdasarkan hasil penelitian dapat ditarik kesimpulan sebagai berikut:

1. Pelaksanaan penilaian pembelajaran Pelaksanaan penilaian pembelajaran yang dilakukan di TK Baitul Uyun, TK Mutiara Ilmu dan TK Cahaya Prima tidak hanya penilaian harian tetapi juga melakukan penilaian semester. Penilaian semester dilaksanakan pada akhir semester pembelajaran, dalam waktu 2 minggu dengan durasi kegiatan $1-1 \frac{1}{2}$ jam untuk masing-masing rombongan belajar. Setiap kelompok diberi tugas berupa beberapa lembar kerja yang berisi materi sesuai aspek perkembangan anak. Materi yang terdapat di dalam lembar kerja merupakan kumpulan dari materi-materi pada setiap tema yang telah dibahas sebelumnya. Materi yang diberikan untuk anak kelompok A dan anak kelompok B ada yang sama namun ada juga yang berbeda.

Berdasarkan uraian tersebut di atas, dapat dikatakan bahwa penilaian semester yang dilakukan di ketiga TK belum menunjukkan kesesuaian dengan prinsipprinsip penilaian pembelajaran di $\mathrm{TK}$, yaitu prinsip alami dan bermakna, otentik, holistik, individual serta multisumber dan multikonteks. Selain itu guru juga belum memahami betul subyek penilaian yaitu anak TK usia 4-6 tahun, hal ini dapat dilihat dari kesamaan materi yang diberikan untuk kelompok anak yang berbeda. Demikian pula halnya dengan pemahaman mengenai sasaran penilaian, dimana aspek yang dinilai lebih banyak pada aspek kognitif dan bahasa, serta penggunaan metode pengumpulan data serta alat penilaian yang lebih dominan menggunakan alat penilaian tes berupa lembar kerja anak.

2. Dampak pelaksanaan penilaian pembelajaran pada penentuan kegiatan pembelajaran selanjutnya. 
Pelaksanaan penilaian pembelajaran khususnya penilaian semester tidak berdampak langsung pada penentuan pembelajaran selanjutnya. Hasil penilaian semester digunakan khususnya bagi anakanak yang menunjukkan hasil kurang maksimal dalam menyelesaikan tugas semester tersebut dengan memberikan kegiatan yang sama pada waktu pembelajaran berikutnya. Kegiatan untuk pembelajaran berikutnya diberikan dengan cara mendiskusikan dengan guru mengenai kegiatan apa yang akan diberikan selanjutnya.

Berdasarkan kesimpulan di atas maka saran yang dapat diberikan adalah sebagai berikut:

1. Sebaiknya sekolah tidak memberikan penilaian semester kepada anak didiknya. Penilaian cukup dilakukan dengan penilaian harian yang dilakukan pada saat anak melakukan kegiatan pada hari itu, sehingga tidak menimbulkan kekhawatiran bagi orangtua dan rasa takut bagi anak didik.

Guru harus dapat memberikan penjelasan kepada orangtua mengenai pentingnya penilaian pembelajaran bagi anak TK yang dilakukan sesuai dengan prinsip-prinsip penilaian pembelajaran

2. Guru perlu memahami benar siapa dan bagaimana anak usia TK sehingga dapat memberikan stimulasi dan melakukan penilaian atas kemampuan anak dengan benar. Hal ini dapat dilakukan dengan cara melakukan diskusi dengan ahli psikologi dan pendidikan atau mengikuti pelatihanpelatihan mengenai tumbuh kembang anak.

3. Guru perlu memahami prinsip-prinsip penilaian pembelajaran di TK serta bermacam-macam metode atau teknik dan alat penilaian untuk menilai kemampuan anak usia dini agar dapat melakukan penilaian dengan benar sehingga memberikan manfaat baik bagi anak didik, bagi guru dan sekolah, serta bagi orangtua dan masyarakat sekitarnya. Hal ini dapat dilakukan dengan cara studi banding ke berbagai lembaga pendidikan anak usia dini, khususnya PAUD dan TK; membaca berbagai literatur mengenai penilaian pembelajaran di TK; maupun berdiskusi dengan ahli pendidikan.

\section{DAFTAR PUSTAKA}

[1] Kementerian Pendidikan dan Kebudayaan. 2003. Undang-undang Republik Indonesia, No. 20 tahun 2003 tentang Sistem Pendidikan Nasional. Jakarta.

[2] Brewer, Jo Ann. 2007. Early Childhood Education Preschool through Primary Grades. Sixth Edition. USA.

[3] Anita Yus. Penilaian Perkembangan Belajar Anak Taman Kanak-Kanak. 2011. Kencana Prenada Media Group, Jakarta.

[4] Slamet Suyanto. 2005. Pembelajaran untuk Anak TK, Depdiknas Dirjen Dikti Dir. Pembinaan Pendidikan Tenaga Kependidikan. Jakarta.

[5] Wolfgang, Charles H., \& Wolfgang, Mary E. 1992. School for Young Children. Developmentally Appropriate Practice. Allyn \& Bacon, USA.

[6] Curtis, Deb \& Carter Margie. 2008. Learning Together with Young Children. A Curriculum Framework for Reflective Teachers. Redleaf Press. New Zealand.

[7] Peraturan Menteri Pendidikan dan Kebudayaan No. 137 Tahun 2014

[8] Ghony, M.Djunaidi \& Almanshur Fauzan. 2012. Metodologi Penelitian Kualitatif. Jogjakarta: Ar Ruzzmedia.

[9] Priyatno, Dwi. 2008. Mandiri Belajar SPSS untuk Analisis Data dan Uji Statistik. Yogyakarta: MediaKom. 